\title{
The East-Central European New Donors: Mapping Capacity Building and Remaining Challenges ${ }^{1}$
}

\author{
Balázs Szent-Iványi ${ }^{\mathrm{a}, \mathrm{b}, 2}$, András Tétényi ${ }^{\mathrm{b}}$ \\ ${ }^{a}$ University of Leeds, Leeds, United Kingdom \\ School of Politics and International Studies (POLIS) \\ Woodhouse Lane, LS2 9JT, Leeds, UK \\ ${ }^{b}$ Corvinus University of Budapest \\ Department of World Economy \\ Fovam ter 8, Budapest H-1093 Hungary
}

\begin{abstract}
In the past decade, the East-Central European countries were provided significant external capacity building assistance in order to help their emergence as donors of foreign aid. This paper aims to map these capacity development programs and identify where they have helped and what challenges remain for the new donors. The main conclusion is that while capacity building has been instrumental in building organizational structures, working procedures and training staff, deeper underlying problems such as low levels of financing, lacking political will, the need for visibility and low staff numbers continue to hinder the new international development policies.
\end{abstract}

Keywords: East-Central Europe, capacity building, foreign aid, new donors

\footnotetext{
${ }^{1}$ The article is based on the needs assessment undertaken within the World Bank Institute (WBI) Capacity Building Program for Emerging European Donors (2011-2013). The statements, findings, interpretations and conclusions expressed in this article are those of the authors and do not necessarily reflect the view of, or are endorsements from the Board of Executive Directors of the World Bank, or the governments they represent.

${ }_{2}^{2}$ Corresponding author. Email: b.szent-ivanyi@leeds.ac.uk
} 


\section{The East-Central European New Donors: Mapping Capacity Building and Remaining Challenges}

\section{Introduction}

The ten East-Central European (ECE) new member states of the European Union (EU) have (re-)emerged as donors of foreign aid in the past ten years. Mainly driven by their accession to the EU, they have all created the necessary organizational and legal structures, and have started financing bilateral and multilateral official development assistance (ODA) programs. These new international development policies however are still rather in their infancy in terms of both quantity and quality, and thus are difficult to compare with the policies of leading established donors like the United Kingdom or Sweden. The ten ECE countries face a number of challenges in development cooperation that include increasing their development spending, securing public support, increasing low administrative capacities and adapting to international norms and recommendations.

In the past decade, several established donors like the Canadian International Development Agency (CIDA), the Swedish International Development Agency (Sida) or the Austrian Development Agency, as well as international organizations like the United Nations Development Program (UNDP) and the European Commission (EC) have provided assistance in the form of capacity building and knowledge sharing to these new donors, helping them in formulating their emerging international development policies. While there are numerous examples of donors learning from each other informally, there have been very few cases of explicit capacity building in other emerging donors, and the scale of the undertaking in the ECE countries is definitely unique and unprecedented. The aim of this paper is to map these capacity building programs, the problems they have addressed and the remaining challenges the ten new donors face. The main finding is that capacity building has played an important role in helping these countries become donors of foreign aid, by introducing them to modern organizational and procedural development practices, assisting them in increasing their resources and exposing them to the global development regime. However, deeper problems, such as the lack of political will to take development cooperation seriously, 
the unwillingness to work together with other donors, or constant organizational and staff constraints remain, and are most likely much more difficult to solve. The paper only concentrates on official development policies, and due to limitations on space does not discuss the challenges other development stakeholders, such as non-governmental organizations face.

The paper contributes to the small but growing literature on the ECE new donors by mapping capacity development programs provided to them, an issue often referred to in the literature but never fully explored (see Bucar and Mrak 2007; Lightfoot, 2008; 2010; Andrespok and Kasekamp, 2012; Oprea 2012). The paper also has important policy implications, for two reasons. First, even after ten years of donorship, the ECE countries are still rather new donors and further capacity building is clearly needed in order to assist them in approximating their practices to OECD Development Assistance Committee (DAC) guidelines and other internationally agreed best practices, such as the Paris Declaration, the Accra Agenda or the Busan Partnership. Second, providers of new donor capacity building assistance can use the lessons learned in the ECE countries to increase the effectiveness of similar programs in countries like Croatia, Turkey and potentially Russia. For example, the UNDP's 'New Development Partnerships' initiative is active in these three countries and may benefit from ECE experience on which capacity development approaches have worked.

The following section provides an overview of the main characteristics of the emerging official development policies in the ECE countries. Section 3 presents research methodology, the main capacity building programs, and their effects in terms of aid quantity, allocation, and quality. Section 4 discusses the challenges ECE donors face today, which have not been solved by capacity building, and section 5 concludes the paper.

\section{The East-Central European Countries as (Re-)Emerging Donors}

Although the ECE donors are often called 'new' or 'emerging' donors of foreign aid, this is not completely precise. Czechoslovakia, Hungary, Poland, Romania and Yugoslavia all had relatively extensive foreign assistance policies during the Communist regimes before 1989, under the name of 'technical and scientific 
cooperation' (Baginski, 2002; Oprea, 2012). During the Cold War the countries of the Eastern Bloc did not have sovereign foreign policies, and thus their international development efforts were also subordinated to the political and military interests of the Soviet Union. These policies consisted mainly of the supply of various equipment, experts and know-how, scholarships and tied credits (Szent-Iványi and Tétényi, 2008). Main recipients included the so-called 'developing socialist brother' countries, like Mongolia, North-Korea, (North-)Viet-Nam, Laos, Cambodia and Cuba, as well as other developing countries which oriented themselves towards the Soviet-bloc at one time or another during the Cold War, such as Angola, Ethiopia, Nicaragua and South-Yemen. Aid programs at the time did not make a difference between development and military aid, and as such had significant military dimensions (HUN-IDA, 2004).

After the transition process began in ECE, all countries ceased their international development activities and turned from being donors to recipients. International organizations like the World Bank and the EC, as well as countries like the United States, Germany, or the Netherlands appeared as donors to support the transition process and provide expertise in building institutions. During the 1990s, the development cooperation activities of the ECE countries were limited to smaller ad hoc contributions to multilateral agencies, humanitarian aid and a limited number of scholarships to students from developing countries.

After the turn of the Millennium however, the eight ECE countries which joined the EU in 2004 (the Czech Republic, Estonia, Hungary, Latvia, Lithuania, Poland, Slovakia and Slovenia) began recreating their international development policies. The process began later in Romania and Bulgaria. The main reason to (re-)establish these policies was external pressure: creating a bilateral international development policy in-line with the spirit of EU's relevant acquis communautaire was an explicit requirement during the accession negotiations (Drozd 2007). Beyond this, the EU voiced little further requirements (Carbone, 2004; Lightfoot, 2010). Development policy in the EU was (and still is) a 'complementary' policy area, with member states retaining full control of their bilateral policies and the EC being responsible for managing aid from the EU's common resources and coordinating member states activities. Thus, there were very little legally binding rules on member state development policies (Horky, 2010), and actual 
implementation was left to the accession countries. Many donors, most notably CIDA, the UNDP and also the EC stepped in to help the accession countries in this process.

Donors had different motivations for providing capacity building. Both CIDA and the UNDP for example were highly active donors in the ECE countries during the transition process, but had begun phasing out their assistance in the early 2000s. CIDA was looking for a 'graceful exit' from the ECE countries, and providing capacity building for development policies seemed an ideal 'final project' for CIDA in the region. ${ }^{3}$ This is more or less true for the UNDP as well, although they were much slower in withdrawing from the region. The EC on the other hand sought to strengthen the new members in order to allow them more meaningful participation in the shaping of the EU's common development policy. ${ }^{4}$

By 2003, all of the eight accession countries had operational development policies and had begun implementing their first bilateral projects. Based on their similar historical, political, socio-economic characteristics, the ECE donors have a number of common characteristics and challenges in their international development policies. These challenges can be placed into three broad groups: increasing aid quantity, dilemmas concerning aid allocation, and issues related to the quality of ECE aid, broadly defined. The following section looks at how external capacity building programs have addressed these three areas. While there is clear evidence of the ECE countries becoming increasingly differentialized and heterogeneous in terms of their international development policies (see Horky-Hluchan and Lightfoot, 2012) their starting positions were highly similar, which warrants treating them as a single group for the purposes of this paper.

\section{The Role of External Capacity Building}

\subsection{Research Methods}

Data were collected in two steps. The first step involved mapping the capacity development programs using a web search methodology, focusing on the websites of OECD DAC donors, major multilateral agencies and the ministries of foreign affairs

\footnotetext{
${ }^{3}$ Interview with an official from CIDA, 19 April 2012.

${ }^{4}$ Interview with an official from the EC, 25 May 2012.
} 
(MFAs) and/or aid implementing agencies of the ECE new donors. Using this approach, it was possible to identify all major capacity development projects that have taken place between 2001 and 2011. In the second step, individual contact persons at the respective agencies were contacted to provide further information, either by granting access to non-public documents (such as concept papers, planning documents, interior evaluation reports, or output documents of the programs) or by providing a possibility for an interview. Another source of information were officials from the foreign ministries of the ECE countries. In all, 21 experts at established donors, international organizations, ECE ministries and implementing agencies (mainly from the Czech Republic and Hungary) provided access to documents or were interviewed. The interviews were carried out between March and May 2012, and mainly focused on the description of capacity building activities, their outputs and outcomes, and the perceptions of the experts on the challenges the new donors continue to face. As the research mainly concentrated on mapping and not a formal evaluation, conclusions related to the impact of the capacity building programs should be seen as highly tentative.

\subsection{Mapping the Programs}

The two largest and most comprehensive capacity building programs were the 'Official Development Assistance in Central Europe’ (ODACE) program, carried out by CIDA and the UNDP's 'Emerging Donors Initiative'. Both of these programs offered a wide range of capacity development activities, including traditional knowledge transfer through training, mentoring, workshops and on-site consultancy, as well as allowing the new ECE donors possibilities for learning by doing through joint programming (CIDA) and the UNDP Trust Funds, both discussed later. ECE countries were able to select the approaches that best suited their needs in both programs, thus the way they were actually implemented varied from one country to another.

The EC was also an important provider of knowledge, with several capacity schemes during the 2000s and starting with more formal training activities and moving to the promotion of joint actions with the new donors more recently. The EC program is the only capacity building program for the new members which is still ongoing in all countries, and the UNDP only remains active in Romania and current accession 
countries like Croatia and Turkey. CIDA, the UNDP and the EC targeted more or less all of the ECE new members. Other capacity development programs either targeted a smaller group of countries, or only focussed on a specific set of activities. The Austrian Development Agency’s Regional Partnership Program for example only included a small joint programming element, where ECE and Austrian NGOs were required to work together in project implementation. The North-South Centre (an autonomous agency of the Council of Europe) on the other hand focused on a single specialized issue, in-line with its mandate of promoting public awareness of global development issues: formalizing development education in the ECE countries. The capacity building programs identified are detailed in Table 1.

\section{$<$ INSERT TABLE 1 HERE $>$}

\subsection{Aid Quantity}

Most of the capacity building programs had a clear component which aimed at increasing ODA expenditures of the ECE countries. Table 2 provides details on the evolution of ODA expenditures, both in absolute terms and as percentage of the countries' gross national incomes (GNI), between 2002 and 2011. There is a clear runup of ODA spending between 2002 and 2006 in most new donors. Based on the interviews, it is argued that a part of this increase can be reasonably attributed to the capacity building programs, for three reasons. First, an important component in the early stages of these programs was to help the new donors to establish ODA delivery mechanisms, tendering and contracting procedures, project cycle management practices, etc. ${ }^{5}$ As there was little experience in the ECE countries on these issues, advice on how to formalize these procedures greatly speeded things up, and allowed most ECE countries to start their bilateral ODA policies in 2003 (and even earlier in the case of the Czech Republic). ${ }^{6}$

\footnotetext{
${ }^{5}$ Interview with an official from CIDA, 19 April 2012.

${ }^{6}$ Interview with an official from an ECE ministry of foreign affairs, 4 April 2012.
} 
Second, the major capacity development programs have all attempted to increase ECE bilateral ODA directly as well, either by providing a framework for the national governments' bilateral expenditures and getting a commitment from the governments on a certain amount of national resources, or by contributing to bilateral development projects on a cost sharing basis. The UNDP for example has supported the creation of Trust Funds with the new donors as an interim institutional solution while these donors gain sufficient experience in their bilateral development policy. The UNDP set up Trust Funds with four new donors: the Czech Republic, Hungary, Romania and Slovakia. These funds were mainly financed by the respective governments, but the UNDP provided overall guidance and a set of procedural rules on how to use these resources. The UNDP managed to secure government contributions of approximately 22 million dollars between 2004 and 2011 for the funds. ${ }^{7}$ Another good example was CIDA's approach, which relied on providing co-financing to certain development projects, implemented in the partner countries by ECE NGOs. CIDA took part in setting the rules for the call for tenders and also co-evaluated the proposals. In total, CIDA contributed to 124 ECE development projects in third countries between 2005 and 2008. ${ }^{8}$ ADA financed a similar cost-sharing exercise, but in their case there was an explicit requirement for ECE NGOs to partner with Austrian ones. ${ }^{9}$

Third, as one interviewee mentioned, the CEE donors at the time knew little about how to report their ODA statistics according to DAC standards. ${ }^{10}$ Almost all capacity development programs included providing training on reporting ODA statistics, and due to these trainings ECE ministry officials were able to 'find' several government expenditures which could be classified as ODA.

While the capacity building programs therefore had a clear impact on ODA quantitative outcomes, it is also clear that other large parts of the increase had nothing to do with the programs, but reflect the fact that after joining the EU in 2004 (or 2007 for Romania

\footnotetext{
${ }^{7}$ Interview with an expert from the UNDP, 11 April 2012.

${ }^{8}$ Internal documents provided by an official from CIDA, 19 April 2012.

${ }^{9}$ Interview with an official from an ECE aid agency, 10 April 2012.

${ }^{10}$ Interview with an official from an ECE MFA, 4 April 2012.
} 
and Bulgaria), the ECE countries began contributing to the community budget, and a portion of these contributions qualifies as ODA.

It is also clear that significant challenges remain in increasing ODA further. As shown in Table 2, the rapid growth in ODA/GNI ratios stopped after 2006, and the past years have been characterized with stagnation, decline and only moderate growth. No ECE country was able to fulfil the 0.17 ODA/GNI target set in the framework of the EU for 2010 (European Commission 2005). None of them have set clear timetables to reach the target for 2015, $0.33 \%$ percent. With the eruption of the global economic crisis in 2008, severe strains were placed on the government budgets of the new members. Development cooperation is a low priority policy area for ECE governments, expenditures on it have little impact on voters, thus budget cuts were especially pronounced here. A further issue is that within ODA, the bulk is made up of multilateral contributions, accounting for more than 75\% of ODA in most ECE countries.

\subsection{Aid Allocation}

The most important partner countries of the ECE donors are selected either from the neighbourhood (i.e. the Western Balkans and the former Soviet countries) or from among the countries with which the ECE countries have had previous (pre-1989) development relations. Iraq and Afghanistan also figure prominently among the most important recipients due to the close alliance of the ECE countries with the United States. Most ECE countries have little activities in Sub-Saharan Africa (Kopinsky 2012) and Latin-America. Aid allocation thus seems to be heavily driven by foreign policy considerations (Andrespok and Kasekamp 2012; Szent-Iványi 2012a).

The capacity development programs have done little to address aid allocation issues, and seem to have taken for granted that the ECE countries concentrate most of their aid in their neighbourhood and not on the poorest countries. Looking at the allocation of aid under the joint programming initiative of CIDA, most of the projects were concentrated in the neighbourhood: in case of Hungary $70 \%$ of the projects were carried out in the Ukraine and Serbia. ${ }^{11}$ Recently, the EC began an initiative to engage the new members

\footnotetext{
${ }^{11}$ Internal documents provided by an official from CIDA, 19 April 2012.
} 
in joint actions, and it chose Moldova as the pilot country. ${ }^{12}$ A notable exception however was the UNDP-Slovak Trust Fund: between 2004 and 2008, more than a quarter of the Trust Fund's total resources were spent in Sub-Saharan Africa (UNDP and SlovakAid 2008: 80), mostly on small scale projects implemented by Slovak NGOs.

Clearly, severe challenges remain in diversifying ECE aid allocation. The EU requires its members to spend at least $15 \%$ of their ODA on least developed countries and also to progressively increase their funding to Africa. On the other hand, the EU also promotes division of labour among donors and urges its members to specialize. The ECE countries argue that they have comparative advantages in their neighbourhood and the costs of being present in regions like Africa are difficult to justify with low bilateral aid levels (Szent-Iványi 2012b). Also, concentrating most of their aid in the neighbourhood seems to be in-line with foreign policy considerations like the need for regional stability, and the promotion of business interests or supporting their ethnic minorities.

\subsection{Aid Quality}

Capacity building programs have attempted to assist the ECE countries in a wide range of issues related to aid quality, such as training on programming methods, advice on institutional set-ups for efficient aid delivery, evaluation, and transparency. Attempts to involve the ECE countries in joint programming activities can also be seen as a way to increase aid quality, in-line with internationally agreed good practices as embodied in the Paris Declaration. From this wide range of qualitative issues, two are discussed here: institutional structures and programming methods.

The governmental institutional structures set up during the capacity development programs are in many cases still working to this day, or new institutional structures have evolved based on them. CIDA's ODACE program was heavily explicit that all CEE countries must prepare an institutional development plan (with CIDA assistance), which would form the backbone for planning and delivering CIDA technical assistance. CIDA experts also drafted detailed staffing plans, operational manuals and other documents for the institutions involved in ODA to use (see for example Norcott 2003). A clear

\footnotetext{
${ }^{12}$ Interview with an official from the EC, 25 May 2012.
} 
success story is the UNDP's involvement in the creation of the Slovak Agency for International Development Cooperation (SlovakAid). The predecessor of the agency was the Administrative and Contracting Unit (ACU), a 'joint venture' of the Slovak MFA and the UNDP, created to manage the administrative side of the UNDP-Slovakia Trust Fund. The unit was gradually strengthened and in 2009 it transformed into a fullyfledged implementation agency (UNDP and SlovakAid 2008). The UNDP also played an important role in supporting capacities at the Czech Development Centre (transforming into the Czech Development Agency in 2008) and the Hungarian International Development Agency (HUN-IDA), although the later has lost its implementing agency status since then. ${ }^{13}$ Many other CEE countries, especially the three Baltic countries, Poland and Slovenia, decided to opt-out of the UNDP Trust Fund scheme, and Romania chose a solution which does not really build national capacities. ${ }^{14}$ Closely related to institutional structures is the second issue, the methods, rules and procedures used to plan, program and deliver ODA (such as project cycle management, programming, tendering and contracting, etc.) and also a more general understanding of development issues. Providing training in these methods was an integral part of most programs, but the CEE donors were also assisted with hands-on consultancy services to define the working procedures of ODA. This was not an easy task as the new procedures needed to be in-line with the regulations of each country. Interviewees mentioned that assistance in formulating these procedures was invaluable, as MFA staff had no experience in these issues. ${ }^{15}$ A good approach was what the Finnish Ministry of Foreign Affairs used in its 'Twinning Light' program in Hungary. Each of the eight training sessions of the program were followed by a session of hands-on mentoring, in which a Finnish expert helped the Hungarian staff members to actually implement the knowledge in their daily work. ${ }^{16}$

\footnotetext{
${ }^{13}$ Clearly, the single implementing agency model was seen by the UNDP and CIDA as something that all CEE countries should strive for. However, convergence to this model proved difficult as it involved centralizing implementation and related funds from line-ministries to a single agency, and was thus resisted by the line-ministries. The reform was only fully successful in the Czech Republic. Lineministries retain important implementation responsibilities in all other ECE countries, even in countries where a formal implementing agency does exist.

${ }^{14}$ Interview with an official from UNDP, 6 April 2012. Romania decided to contribute to UNDP-run projects in countries like Georgia or Moldova, instead of launching its own development projects with UNDP assistance like the other countries.

${ }^{15}$ Interview with an official from an ECE ministry of foreign affairs, 4 April 2012.

${ }^{16}$ Internal documents provided by an official from the Finnish Ministry of Foreign Affairs, 18 April 2012.
} 


\section{Remaining Challenges}

The research has revealed a number of areas which development experts at established donors, ECE countries and international organizations see as particularly pressing. When asked to talk about challenges that still need to be addressed, most interviewees mentioned strikingly similar issues, and these resonate well with some of the issues identified by the OECD DAC in its special reviews of the Czech Republic, Poland, Slovenia and Slovakia. Five of these issues are discussed below.

First, increasing aid quantity does not only depend on international commitments and the availability of budgetary resources, but also on the willingness of governments. Government attitudes towards ODA are still problematic (see also OECD 2011a: 15). Many capacity development programs attempted to involve politicians, CIDA for example organized a study tour for them to Canada to see how politicians there are involved in development cooperation. There were a handful of conferences and workshops to which politicians were also invited. In most ECE countries (Hungary, Lithuania, Latvia, Poland, Slovakia and Romania in particular), development cooperation is still very far from being embedded in daily politics and thus has little political support and low visibility. One expert interviewed emphasized that any future capacity development project is likely to have little impact unless the apathy and lack of willingness to go forward that seems to be prevalent towards ODA in many (though not all) of the ECE governments is addressed. ${ }^{17}$ All this is well illustrated by the following quote from a senior ECE diplomat: “Don’t have any illusions. If the EU didn’t require us to do development policy, we wouldn’t be doing it. The returns are just too small.”"18 This is not an obstacle that could be overcome quickly, and improving development education can play a role by making people aware of development issues, who in turn could then put greater pressure on politicians.

A second issue revolves around the fact that the ECE countries wish to preserve their visibility as donors and seem unwilling to compromise on strategic goals. ${ }^{19}$ This is shown well by the mixed results of later capacity development programs which focused

\footnotetext{
${ }^{17}$ Interview with a development expert at an international organization, 25 March 2012.

${ }^{18}$ Interview with an official from an ECE ministry of foreign affairs, 5 May 2012.

${ }^{19}$ Interview with an official at a Western development agency, 15 April 2012.
} 
on joint programming. Both USAID and Sida initiated programs in the region with the aim of using the regional experience of the new donors in projects in the post-Soviet region and the Balkans. According to an expert interviewed, Sida’s Partnership Program attracted only limited interest from the ECE countries, which can be traced back to the fact that Sida's approach was difficult to reconcile with the preferences of the ECE countries. $^{20}$ Whereas Sida supported an approach based on the needs of the partner countries, this thinking proved to be new for the ECE partners. The new EU member states were working mainly through financing national NGOs which then implemented their own project ideas in the recipient countries. Line-ministries and their own partners seemed to work rather independently from the MFAs. Creating true joint projects would involve harmonizing procedures and also strategic goals, but the ECE countries did not seem ready to compromise on these. Issues on visibility are also mentioned in some of the special reviews (OECD 2011a: 16; 2011b: 9).

Third, strategic thinking and planning is still not sufficiently present. Drafting ODA strategies, as well as country assistance strategies was an important component both in CIDA's and the UNDP's programs, but these efforts did not prove sustainable. Strategic thinking seems to be present in only a limited number of ECE countries, mainly the Czech Republic, Estonia, and Slovenia (OECD 2011b: 12). Several interviewees mentioned that they feel that ECE ODA policies are rather ad hoc, without any clear strategic direction. ${ }^{21}$ Many of the ECE countries do not have operational country assistance strategies, which makes much of their assistance donor-driven and ad hoc. Hungary for example has never had an operational ODA strategy, and the first country strategies drafted in the late 2000s were never operationalized either. A symptom of the lack of strategic thinking is the excessively large number of partner countries that almost all ECE donors have. ${ }^{22}$

The fourth issue is evaluation and learning from results. Most experts interviewed mentioned impact evaluation as an issue where further capacity development is needed. ECE countries neglect evaluation almost totally, and at best only carry out financial monitoring of their development activities (the Czech Republic and to some extent

\footnotetext{
${ }^{20}$ Interview with an official from Sida, 19 April 2012.

${ }^{21}$ Interview with an expert from an international organization, 11 April 2012.

${ }^{22}$ In 2010 for example, Hungary divided its bilateral aid budget of a mere 22 million dollars among more, than 70 partner countries (OECD 2012).
} 
Slovakia are perhaps exceptions). This lack of attention to evaluation is not only a question of resources, but one of mentality. ${ }^{23}$ In most ECE countries there is little culture of evaluation in the government sector, and governments seem to perceive evaluation as source of criticism on their activities, not a possibility for learning and improving policies. The problem therefore is one which cannot be solved with capacity building, but it requires attempts to form government attitudes on the topic and fostering a culture of evaluation (OECD, 2010: 10; 2011a: 31; 2011b: 30).

Fifth, staff capacity problems remain due to two reasons: development staff numbers in ECE MFAs are low and turnover among them is high (see also: OECD, 2007: 17-18; 2010: 10; 2011a: 25; 2011b: 26). Development departments and implementing agencies are often understaffed, for example, in early 2012, there were only 8 experts working on development cooperation in the Hungarian MFA and 4 in Bulgaria. Staff members taking part in trainings, study visits, internships etc. during the capacity building programs were often rotated away afterwards to different jobs or foreign missions. Many staff members actively sought new assignments, as the prestige of development cooperation was rather low in some MFAs. Clearly, frequent changes in development staff means that much of the knowledge transferred may be lost, leading to severe effectiveness and sustainability problems in the capacity building programs. ${ }^{24}$ It is not clear how future capacity building programs could address this issue.

\section{Conclusions}

This paper presented the results of a mapping exercise of capacity building programs offered to the ECE new donors between 2001 and 2011. Despite the fact that these donors have received important external assistance in formulating their international development policies, substantial challenges remain. Capacity building programs have contributed to increasing ODA, the creation of basic institutional structures and operating procedures, as well as training staff in how to do development cooperation, but issues like low aid quantity, the lack of political willingness, the need to preserve

\footnotetext{
${ }^{23}$ Interview with an expert from an international organization, 11 April 2012.

${ }^{24}$ A strikingly negative and most likely not unique example was when the Foreign Ministry of Finland provided an internship opportunity for a development staff member from the Hungarian MFA at the Finnish embassy in Nairobi, Kenya. Shortly after her return to Budapest, the former intern was moved to the consular department and appointed to the Hungarian consulate in Helsinki.
} 
visibility, problems with strategic thinking and low staff numbers still plague ECE bilateral development policies.

One cannot help to think that the capacity building programs provided to the ECE donors mainly only helped in introducing formal institutions and procedures, but did not change underlying mentalities. The capacity building programs clearly had an important role in exposing ECE officials to the global development regime: development staff have learned to 'talk the talk' of international development cooperation, but decision makers may not be convinced of the need to take development cooperation seriously. Ten years ago, when ODA was a new issue, and there was clear external pressure to do something in the policy area due to the EU accession process, governments were more likely to heed external advice then they are today, when almost all such pressure has disappeared. National willingness is the only factor that can serve as a driving force today, and in the case of most ECE countries it is missing. This lack of willingness may signify that the ECE countries are 'premature' donors: they became donors of foreign aid before they were actually ready for it.

Last, but not least, what have the providers of capacity building assistance learned? The fact that neither of these donors has carried out any formal impact evaluation of their project is telling: they have most likely seen these projects as one-off and highly specific. However, as some new donor capacity building programs are still active and such programs may be useful in building linkages with some of the non-DAC donors like Brazil, India or Russia, donors should be encouraged to learn from their experience in the ECE region. This paper has revealed that some capacity building approaches have worked better than others, but these conclusions need to be refined with more formal impact evaluations.

\section{References}

Andrespok E, Kasekamp AI. 2012. Development Cooperation of the Baltic States. Perspectives on European Politics and Society, 13(1): 117-130.

Baginski P. 2002. Poland. In EU Eastern enlargement and development cooperation, Dauderstädt M (ed.). Bonn: Friedrich-Ebert-Stiftung.

Bucar M, Mrak M. 2007. Challenges of development cooperation for EU New member states. Presented at the ABCDE World Bank Conference, Bled, Slovenia, May 17-18, 2007. 
Carbone M. 2004. Development Policy. In European Union Enlargement, Nugent N (ed.). Basingstoke, UK: Palgrave.

Drozd M. 2007. The New Face of Solidarity: A Brief Survey of Polish Aid, Manuscript. http://papers.ssrn.com/sol3/Delivery.cfm/SSRN_ID1132246 code948600.pdf?abstractid=11 32246\&mirid=2, (21 May 2009).

European Commission. 2005. Speeding up progress towards the Millennium Development Goals - The European Union's contribution. Brussels: European Commission.

Horky O. 2010. The Europeanisation of Development Policy. Acceptance, accommodation and resistance of the Czech Republic. DIE Discussion Paper 18/2010.

Horky O. 2012. The Transfer of the Central and Eastern European 'Transition Experience' to the South: Myth or Reality? Perspectives on European Politics and Society 13(1): 17-32.

Horky-Hluchan O, Lightfoot S (eds). 2012. Development Policies of Central and Eastern European States. From Aid Recipients to Aid Donors. London: Routledge

HUN-IDA, 2004. A magyar müszaki-tudományos együttmüködés és segitségnyújtás négy évtizedének rövid áttekintése napjainkig. [An overview of the four decades of Hungarian technical-scientific cooperation and assistance]. Budapest: Hungarian International Development Agency.

Kopinsky D. 2012. Visegrad Countries' Development Aid to Africa: Beyond the Rhetoric. Perspectives on European Politics and Society 13(1): 33-49.

Lightfoot S. 2008. Enlargement and the challenge of EU development policy. Perspectives on European Politics and Society 9(2): 128-142

Lightfoot, S., 2010. The Europeanisation of International Development Policies: The Case of Central and Eastern European States. Europe-Asia Studies 62 (2), 329-350.

Norcott NE. 2003. Recommendations to Strengthen the Institutional Capacity of Hungary to Manage and Deliver Its ODA Program. Ottawa: CIDA.

OECD 2007. DAC Special Review of the Czech Republic. Paris: OECD

OECD 2010. DAC Special Review of Poland. Paris: OECD

OECD 2011a. DAC Special Review of the Slovak Republic. Paris: OECD

OECD 2011b. DAC Special Review of Slovenia. Paris: OECD 
http://www.oecd.org/dac/aidstatistics/internationaldevelopmentstatisticsidsonlinedatabaseson aidandotherresourceflows.htm (7 March 2013).

Oprea M. 2012. Development Discourse in Romania: From Socialism to EU Membership. Perspectives on European Politics and Society 13(1): 66-82.

Szent-Iványi B, Tétényi A. 2008. Transition and foreign aid policies in the Visegrád countries. Transition Studies Review 15(3): 573-587.

Szent-Iványi B. 2012a. Aid Allocation of the Emerging Central and Eastern European Donors. Journal of International Relations and Development 15(1): 65-89.

Szent-Iványi B. 2012b. Hungarian international development co-operation: context, stakeholders and performance. Perspectives on European Politics and Society, 13(1): 50-65.

UNDP. 2006. Emerging Donors Initiative. Bratislava: UNDP

UNDP, SlovakAid. 2008. Slovakia-UNDP Trust Fund, Summary Report 2003-2008. Bratislava: UNDP. 


\section{Tables}

Table 1. Major capacity building programs for the new ECE donors

\begin{tabular}{|c|c|c|c|}
\hline Donor & Title of the program & Duration & $\begin{array}{c}\text { Beneficiary ECE } \\
\text { countries * }\end{array}$ \\
\hline $\begin{array}{l}\text { Canadian International } \\
\text { Development Agency } \\
\text { (CIDA) }\end{array}$ & $\begin{array}{l}\text { Official Development Assistance in } \\
\text { Central Europe (ODACE) }\end{array}$ & $2001-2008$ & $\begin{array}{l}\text { Cz, Es, Hu, Li, Lt, Pl, } \\
\text { Sk, Si }\end{array}$ \\
\hline $\begin{array}{l}\text { Austrian Development } \\
\text { Agency (ADA) }\end{array}$ & Regional Partnership Program (RPR) & $2005-2007$ & $\mathrm{Cz}, \mathrm{Hu}, \mathrm{Sk}, \mathrm{Si}$ \\
\hline $\begin{array}{l}\text { United States Agency for } \\
\text { International Development } \\
\text { (USAID) }\end{array}$ & Emerging Donors Initiative (EDI) & 2006-2009 & $\begin{array}{l}\mathrm{Bu}, \mathrm{Cr}, \mathrm{Cz}, \mathrm{Hu}, \mathrm{Pl}, \mathrm{Ro} \text {, } \\
\text { Sk, Si }\end{array}$ \\
\hline $\begin{array}{l}\text { Japan International } \\
\text { Cooperation Agency (JICA) }\end{array}$ & no systematic program & $2006-2008$ & $\mathrm{Pl}$ \\
\hline $\begin{array}{l}\text { Ministry of Foreign Affairs of } \\
\text { the Netherlands }\end{array}$ & $\begin{array}{l}\text { Strengthening the Implementing } \\
\text { Capacity for ODA }\end{array}$ & $2006-2007$ & $\mathrm{Hu}$ \\
\hline Foreign Ministry of Finland & Twinning Light & 2007 & $\mathrm{Hu}$ \\
\hline $\begin{array}{l}\text { Swedish International } \\
\text { Development Agency (Sida) }\end{array}$ & Partnership Program & 2009- & $\begin{array}{l}\text { Offered to all, with Es, } \\
\text { Pl, Ro, Sk, Si being } \\
\text { more involved }\end{array}$ \\
\hline $\begin{array}{l}\text { United Nations Development } \\
\text { Program (UNDP) }\end{array}$ & Emerging Donors Initiative & $2003-$ & $\begin{array}{l}\text { Cr, Cz, Es, Hu, Li, Lt, } \\
\text { Pl, Ro, Sk, Si, Tk }\end{array}$ \\
\hline European Commission (EC) & $\begin{array}{l}\text { Emerging Donors Capacity Building } \\
\text { Schemes I-IV }\end{array}$ & 2004- & $\begin{array}{l}\mathrm{Bu}, \mathrm{Cz}, \mathrm{Es}, \mathrm{Hu}, \mathrm{Li}, \mathrm{Lt}, \\
\mathrm{Pl}, \mathrm{Ro}, \mathrm{Sk}, \mathrm{Si}\end{array}$ \\
\hline $\begin{array}{l}\text { Council of Europe North- } \\
\text { South Centre (CoE-NSC) }\end{array}$ & $\begin{array}{l}\text { Strengthening Global Education in } \\
\text { the Visegrad countries }\end{array}$ & $\begin{array}{l}\text { 2004-2005 } \\
\text { and 2009- } \\
2011\end{array}$ & $\begin{array}{l}\mathrm{Cz}, \mathrm{Hu}, \mathrm{Pl}, \mathrm{Sk} \text { in the } \\
\text { first phase, later all } \\
\text { others }\end{array}$ \\
\hline
\end{tabular}

* Country abbreviations are the following: $\mathrm{Bu}$ - Bulgaria, Cr - Croatia, Cz - Czech Republic, Es Estonia, Hu - Hungary, Li - Lithuania, Lt - Latvia, Pl - Poland, Ro - Romania, Sk - Slovakia, Si Slovenia. 
Table 2. Net ODA disbursements in million dollars and as a percentage of gross national income in the ECE new donors, 2002-2011

\begin{tabular}{|c|c|c|c|c|c|c|c|c|c|c|}
\hline & 2002 & 2003 & 2004 & 2005 & 2006 & 2007 & 2008 & 2009 & 2010 & 2011 \\
\hline \multirow{2}{*}{$\begin{array}{l}\text { Czech } \\
\text { Republic }\end{array}$} & 86 & 147 & 154 & 180 & 201 & 194 & 227 & 210 & 228 & .. \\
\hline & 0.07 & 0.10 & 0.11 & 0.11 & 0.12 & 0.11 & 0.12 & 0.12 & 0.13 & 0.13 \\
\hline \multirow{2}{*}{ Estonia } & 3 & 2 & 7 & 13 & 17 & 16 & 20 & 18 & 19 & 22 \\
\hline & .. & .. & 0.05 & 0.08 & 0.09 & 0.08 & 0.10 & 0.10 & 0.10 & 0.12 \\
\hline \multirow{2}{*}{ Hungary } & .. & 30 & 86 & 118 & 179 & 103 & 96 & 117 & 114 & 133 \\
\hline & .. & 0.03 & 0.06 & 0.11 & 0.13 & 0.08 & 0.08 & 0.10 & 0.09 & 0.11 \\
\hline \multirow{2}{*}{ Latvia } & 2 & 1 & 10 & 12 & 13 & 16 & 21 & 21 & 16 & 18 \\
\hline & .. & 0.01 & 0.06 & 0.07 & 0.06 & 0.06 & 0.07 & 0.08 & 0.06 & 0.07 \\
\hline \multirow{2}{*}{ Lithuania } & 2 & 2 & 11 & 18 & 28 & 49 & 47 & 37 & 37 & 48 \\
\hline & .. & 0.01 & 0.04 & 0.06 & 0.08 & 0.11 & 0.11 & 0.11 & 0.10 & 0.13 \\
\hline \multirow{2}{*}{ Poland } & 24 & 43 & 167 & 252 & 345 & 361 & 317 & 392 & 378 & 399 \\
\hline & .. & 0.01 & 0.05 & 0.07 & 0.09 & 0.10 & 0.08 & 0.09 & 0.08 & 0.08 \\
\hline \multirow{2}{*}{ Romania } & .. & .. & .. & .. & .. & .. & 120 & 154 & 114 & 153 \\
\hline & .. & .. & .. & .. & .. & 0.07 & 0.08 & 0.09 & 0.07 & 0.09 \\
\hline \multirow{2}{*}{ Slovakia } & 16 & 28 & 43 & 82 & 74 & 75 & 87 & 72 & 74 & 80 \\
\hline & 0.02 & 0.05 & 0.07 & 0.12 & 0.10 & 0.09 & 0.10 & 0.09 & 0.09 & 0.09 \\
\hline \multirow{2}{*}{ Slovenia } & .. & .. & .. & 42 & 51 & 56 & 63 & 67 & 59 & 60 \\
\hline & .. & .. & .. & 0.11 & 0.12 & 0.12 & 0.13 & 0.15 & 0.13 & 0.13 \\
\hline $\begin{array}{l}\text { OECD DAC } \\
\text { average }\end{array}$ & 0.23 & 0.25 & 0.26 & 0.33 & 0.31 & 0.28 & 0.31 & 0.31 & 0.32 & 0.31 \\
\hline
\end{tabular}

Source: OECD (2013). Absolute figures are in constant 2010 dollars.

Note: Bulgaria does not report ODA figures to the OECD DAC. 